\title{
MODEL SISTEM INFORMASI MANAJEMEN SEKOLAH BERBASISKAN NOTASI UNIFIED MODELING LANGUAGE
}

\author{
Yohannes Kurniawan \\ Information Systems Department, School of Information Systems, Binus University \\ Jl. K.H. Syahdan No. 9, Palmerah, Jakarta Barat 11480 \\ ykurniawan@binus.edu
}

\begin{abstract}
Basically the use of integrated information systems can be applied not only for the company, but also education industry, particularly schools. To support business processes at the school, this research would like to describe a conceptual model of information systems using the Unified Modeling Language (UML) notation with "4 +1 View" architectural model. This model is expected to assist analysis and design the whole business processes at school. A conceptual model of the information system can help application developers to easily and clearly understand the school system. By adopting this information system model, schools are able to have effective understanding of management information systems.
\end{abstract}

Keywords: information systems, unified modeling language, school management

\begin{abstract}
ABSTRAK
Pada saat ini penggunaan sistem informasi telah diterapkan oleh perusahaan untuk mendukung proses bisnis pada perusahaan secara real time dan terintegrasi. Penggunaan sistem informasi manajemen terintegrasi ini pada dasarnya dapat diterapkan bukan hanya pada perusahaan saja, tetapi juga dalam industri pendidikan khususnya sekolah. Pada penelitian ini, peneliti ingin menggambarkan model sistem informasi manajemen untuk mendukung proses bisnis yang terdapat pada sekolah. Model konseptual sistem informasi manajemen untuk sekolah ini digambarkan dengan mengunakan notasi Unified Modeling Language (UML) dengan pendekatan model arsitektur " $4+1$ View". Model ini diharapkan dapat membantu analisis dan perancangan proses bisnis pada sekolah secara keseluruhan. Model konseptual sistem informasi ini dapat membantu pengembang aplikasi sekolah untuk mengerti sistem secara jelas dan mengembangkan sistem menjadi lebih mudah. Dengan mengadopsi model sistem informasi manajemen ini, sekolah dapat memperoleh pengertian tentang sistem informasi manajemen menjadi lebih efektif.
\end{abstract}

Kata kunci: sistem informasi, unified modeling language, manajemen sekolah, 


\section{PENDAHULUAN}

Sistem pendidikan di Indonesia membutuhkan sebuah revolusi. Banyak praktisi pendidikan yang mempertanyakan rendahnya kualitas pendidikan di Indonesia. Berbicara mengenai kualitas sebenarnya adalah hal yang sulit, karena kualitas itu sendiri merupakan suatu variabel non-parametrik. Banyak teori-teori pendidikan yang mendasarkan tolak ukur kualitas pendidikan itu dinilai dari hasil output pendidikan itu sendiri, yaitu kualitas siswa. Namun, ada pula yang mendasarkan pengukuran kualitas pada nilai efektifitas proses pendidikan.

Salah satu cara untuk peningkatan mutu pendidikan tersebut adalah dengan mengadopsi Teknologi Informasi dan Komunikasi (TIK) dalam proses manajemen sekolah. Teknologi yang semakin berkembang menyediakan kesempatan yang sangat besar untuk mengembangkan manajemen pendidikan dan proses pembelajaran di sekolah. Teknologi informasi saat ini memiliki prioritas yang tinggi dalam pendidikan. Pada saat ini, kontribusi teknologi informasi untuk pendidikan telah menjadi subjek utama yang menjadi sorotan (Webber, 2003).

TIK yang beberapa tahun belakangan ini berkembang di berbagai perusahaan adalah penggunaan sistem informasi yang sudah sangat meluas dan maju sehingga sudah menjadi suatu kebutuhan penting bagi perusahaan - perusahaan besar di dunia. Salah satu studi menunjukkan bahwa 33\% perusahaan memperoleh penghematan biaya dalam manajemen pesanan penjualan, dan 34\% mengatakan bahwa sistem informasi mereka sangat mengurangi kebutuhan jumlah karyawan (Weber, 2000). Penggunaan sistem informasi manajemen saat ini bukan hanya dapat diterapkan pada perusahaan saja, tetapi juga dapat diterapkan pada sekolah.

Dengan implementasi suatu sistem informasi manajemen ini diharapkan sekolah dapat memperoleh manfaat terwujudnya suatu pusat informasi yang dapat diakses oleh siswa, guru maupun orangtua/wali siswa untuk memperoleh data-data pendidikan yang terkait dengan kewenangannya. Beberapa masalah yang sering dihadapi sekolah dalam melaksanakan pengendalian manajemen pendidikan di sekolah antara lain adalah: (1) layanan pendidikan kepada siswa kurang optimal; (2) kekurang-paduan antara data dan informasi antar komponen-komponen manajemen sekolah; (3)tidak adanya kolaborasi yang mempermudah koordinasi; (4) akuntabilitas tidak berkesinambungan; (5) penyediaan informasi tidak cepat dan tepat guna. jadi manfaat yang akan diperoleh dengan sistem informasi manajemen ini tidak hanya dirasakan oleh elemen sekolah saja (termasuk civitas akademika, alumni, orangtua dan masyarakat), melainkan juga oleh Dinas Pendidikan Nasional.

Pemodelan sistem yang kompleks terdiri dari banyak proses. Secara ideal keseluruhan sistem tersebut dapat digambarkan dalam single diagram. Single diagram menjelaskan tentang keseluruhan sistem secara tidak ambigu dan mudah untuk dikomunikasikan dan dimengerti, karena keseluruhan sistem diidentifikasi pada satu waktu (Kruchten, 2012). Pada dasarnya tidak memungkinkan dan sangat sulit untuk menggambarkan keseluruhan sistem dalam single diagram. Karena mayoritas proses bisnis pada perusahaan sangat besar dan kompleks. Jika hanya menggunakan single diagram tidak dapat menggambarkan seluruh informasi dalam keseluruhan sistem yang ada (Kruchten, 2012).

UML merupakan bahasa standar dalam pemodelan yang diadopsi dari Object Management Group pada tahun 1977. UML sebagai bahasa pemodelam menggambatkan model sistem (real world dan software) berbasiskan konsep objek (Hitz dan Kappel, 1999). Sejak UML digunakan untuk menggambarkan beberapa tipe sistem, UML dapat digunakan untuk pemodelan sistem, dengan cakupan yang lebih luas (Arlow, et al., 1999). UML berisi dua tools yang vital: notasi dan meta-model (Hruby, 1998). Notasi merupakan satu set sintaks diagram, yang memungkinkan anda untuk menganalisis dan merancang sistem. Meta- model adalah definisi dari notasi. UML berisi notasi yang kaya dan kompleks untuk menggambarkan sistem (Hruby, 1998). Perspektif adalah view yang 
digunakan untuk melihat dan menggambarkan sistem dari aspek yang berbeda dari user requirement. Pada penelitian ini, penulis mendiskusikan beragam pandangan dari stakeholders untuk menggambarkan model sistem informasi manajemen.

Ketika penulis memodelkan sistem informasi manajemen ini, sistem digambarkan dalam beberapa aspek: fungsional, non-fungsional, dan organisasional. Bagaimanapun, sistem ini dapat menggambarkan beberapa pandangan, seperti pandangan dari proyeksi dari gambaran sistem secara lengkap.

Pendekatan sistem arsitektur untuk mengambarkan sistem dengan menggunakan Diagram UML dapat direpresentasikan dengan pendekatan “4+1" views seperti pada Gambar 1 (Jacobson, et al., 1999). Pendekatan ini memungkinkan pengembang untuk menggambarkan esensial karakteristik dari sistem yang kompleks (Kruchten, 2012). Berikut merupakan penjelasan pandangan - pandangan dari pendekatan pada pendek“4+1” views pada: (1) the logical view - merepresentasikan elemen struktural, tingkat abstraksi, dan frekuensi penggunaan model object oriented; (2) the process view merepresentasikan aspek eksekusi dari sistem: pola interaksi dan hubungannya; (3) the implementation view -; merepresentasikan dekomposisi dalam subsistem yang digunakan dalam lingkungan pengembangan sistem (view development); (4) the deployment view - merepresentasikan kerangka distribusi dari komponen perangkat lunak pada physical nodes, computer atau processor yang digunakan; (5) + 1 the use case view - merepresentasikan use case/ skenario yang melibatkan multiple actor.

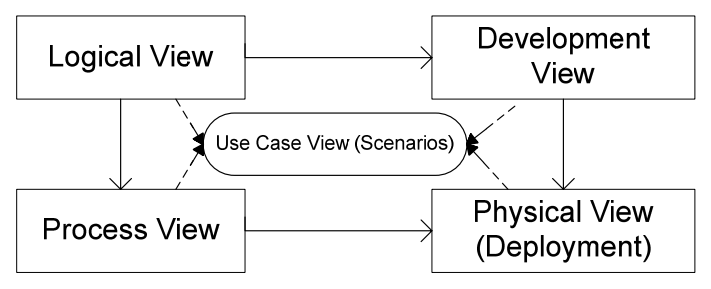

Gambar 1 Model “4+1” views

Pada penelitian ini, penulis mengusulkan model untuk sistem informasi manajemen pada Sekolah dengan menggunakan pendekatan " $4+1$ " views untuk pemodelan sistem berdasarkan notasi Unified Modeling Language (UML). Dengan model ini akan membantu analisis kebutuhan bagi pihak pengembang sistem menjadi lebih mudah untuk direalisasikan. Model sistem informasi manajemen dapat menjelaskan kompleksitas sistem menjadi lebih umum dan dapat membantu manajer proyek yang tidak memiliki keahlian teknik untuk lebih mudah mengerti sistem informasi ini (Carl dan Lessing, 2005). Selain itu, modeling framework juga dapat digunakan untuk mengomptimalkan proses implementasi sistem informasi, seperti yang dilakukan pada saat implementasi sistem pada Mexican University, Panamerican University of Mexico (Worley, Chatha, Weston, Aguirre, dan Grabot, 2005).

Pada penelitian ini, penulis merepresentasikan model sistem informasi manajemen dengan UML (teknik pemodelan berorientasi object). Dengan menggunakan model ini, pengembang sistem informasi manajemen untuk sekolah akan memperoleh keuntungan. Model sistem informasi manajemen mengikuti perancangan dan implementasi yang dapat digunakan sepanjang pengembangan sistem, karena adanya batasan antara analisis, perancangan, dan implementasi. Model sistem informasi manajemen akan menyederhanakan fungsionalitas dari sistem ini. Dengan menyederhanakan sistem ini akan membuat kebutuhan sistem informasi manajemen untuk sekolah akan semakin mudah dimengerti. Pada umumnya, sistem yang baik adalah yang mudah dimengerti, diimplementasikan, dan dipelihara oleh pengguna maupun pengembangnya (Park dan Lee, 2006). 


\section{METODE}

Metode penulisan yang digunakan dalam penelitian ini adalah kualitatif. Pengumpulan data dalam analisis model sistem informasi manajemen ini dilakukan dengan mengumpulkan dokumen input dan output yang mengalir didalam sekolah, serta memperhatikan semua sistem informasi yang sedang berjalan dan yang akan dikembangkan sebagai sumber data primer, dengan teknik pengumpulan data secara langsung yang terdiri dari: (1) wawancara, dilakukan dengan cara tanya jawab secara langsung kepada pihak yang berkepentingan dalam penelitian ini; (2) pengamatan (observation), di mana penulis melakukan pengamatan langsung terhadap proses bisnis terkait dengan TI yang berlangsung pada sekolah, dalam hal ini BINUS Internasional School. Sedangkan untuk pengumpulan data tidak langsung diperoleh melalui buku dan berbagai jurnal. Dokumentasi dari hasil analisis model informasi manajemen untuk sekolah ini menggunakan unified modeling language yang didasarkan pada pendekatan arsitektur " $4+1$ views” (Kruchten, 2012).

\section{HASIL DAN PEMBAHASAN}

Pada dasarnya setiap sekolah memiliki struktur organisasi dan proses bisnis yang serupa. Atas dasar hal tersebut dengan mengembangkan satu sistem informasi manajemen sekolah dapat memenuhi kebutuhan yang terdapat pada sekolah. Pada penelitian ini, penulis mengenalkan model sistem informasi manajemen untuk sekolah berdasarkan fungsionalitas proses bisnis pada sekolah, meliputi: registrasi siswa baru, penjadwalan dan persiapan sekolah, kegiatan teaching dan learning, evaluation, dan graduation (Ranjan dan Khalil, 2007).

Sistem informasi manajemen sekolah adalah sebuah terminologi sistem informasi yang mendukung transaksi atau operasi sehari-hari dalam pengelolaan sumber daya perusahaan. Sedangkan penerapan konsep-konsep sistem informasi manajemen tersebut dalam industri pendidikan secara garis besar adalah sama dengan sistem informasi manajemen pada perusahaan. Ketika sebuah konsep mengenai otomatisasi transaksional di sekolah dipikirkan, beberapa aspek yang masuk dalam pembahasan adalah manajemen pembelajaran, manajemen pembayaran, perpustakaan, dan lain-lain. Mungkin beberapa institusi pendidikan telah memiliki sebagian atau beberapa aplikasi-aplikasi seperti itu, namun sifatnya stand-alone, yaitu tidak saling memiliki keterkaitan satu sama lain antar sistemnya.

Manajemen pendidikan di sekolah merupakan proses-proses yang terorganisir untuk pengelolaan komponen-komponen pendidikan di sekolah, yaitu: kurikulum dan program pengajaran, tenaga kependidikan, kesiswaan, keuangan, pengelolaan hubungan sekolah dan masyarakat, serta keorganisasian sekolah itu sendiri. Beberapa masalah yang sering dihadapi sekolah dalam melaksanakan pengendalian manajemen pendidikan di sekolah yang menjalankan roda-roda manajemen tanpa menggunakan perangkat bantu manajemen (management tools) antara lain adalah: (1) layanan pendidikan kepada siswa kurang optimal; (2) kekurang-paduan antara data dan informasi antar komponen-komponen manajemen sekolah; (3) tidak adanya kolaborasi yang mempermudah koordinasi; (4) akuntabilitas tidak berkesinambungan; (5) penyediaan informasi tidak cepat dan tepat guna.

Sistem informasi manajemen untuk sekolah merupakan seperangkat sistem informasi berbasiskan web terintegrasi yang terdiri dari empat portal utama, yaitu: (1) staff desk sebagai portal yang digunakan oleh guru dan pegawai sekolah untuk mengakses berbagai informasi yang dibutuhkan terkait kegiatan akademik; (2) student desk sebagai portal informasi bagi para siswa aktif di sekolah untuk mengakses informasi yang diperlukan; (3) parent desk sebagai portal informasi bagi orang 
tua/wali murid untuk mengakses informasi terkait dengan perkembangan anak di sekolah; (4) alumni desk sebagai portal informasi untuk menjalin komunitas dengan para alumni sekolah.

Tujuan dari pembangunan aplikasi sistem informasi manajemen ini nantinya adalah untuk memberikan solusi terintegrasi terhadap pengelolaan kegiatan-kegiatan di sekolah pada jenjang pendidikan dasar dan menengah (SD/MI hingga SMA/SMK/MA) sehingga dapat mempermudah elemen-elemen sekolah dalam memanajemen sekolah dan memfokuskan kegiatan pada peningkatan mutu pendidikan dan peningkatan mutu pengelolaan pendidikan sehingga memberikan hasil berupa output pendidikan yang berkualitas.

Jika ingin melihat sistem secara keseluruhan, hal ini akan sangat kompleks. Salah satu cara untuk melihatnya jika kita menggunakan pendekatan diagram 4+1 views dengan memecahkan sistem menjadi lima bagian/ view. Model ini mempertimbangkan dan mendokumentasikan lima tingkat aspek penting dari sistem. Pendekatan ini dipecahkan dalam pemodelan sistem dengan mengikuti view (termasuk use case view). View ini menampilkan komponen-komponen (object-object) sistem yang saling berinteraksi/berhubungan. Diagram UML dapat membantu untuk mengilustrasikan use case, logical, process, development (implementation), dan physical view dari sistem untuk membantu pengembangan sistem informasi.

\section{Use Case View}

Use case view (scenario view) dimodelkan dengan menggunakan UML Use case diagram. Use case diagram digunakan untuk memodelkan fungsionalitas sistem yang menggambarkan interaksi antara sistem dengan actor. Tujuan dari penggambaran use case diagram digunakan untuk mengambarkan konteks dari sistem informasi manajemen. Pada penelitian ini penulis menggambarkan dua diagram system use case yang mendefinisikan high level proses dalam sistem informasi manajemen Sekolah secara keseluruhan (Gambar 2) dan low level use case diagram (Gambar 3). Pada Gambar 2, model sistem informasi manajemen dipecah menjadi empat use case yang merepresentasikan portal dari sistem informasi manajemen sekolah: staff desk, parent desk, student desk, dan alumni desk.

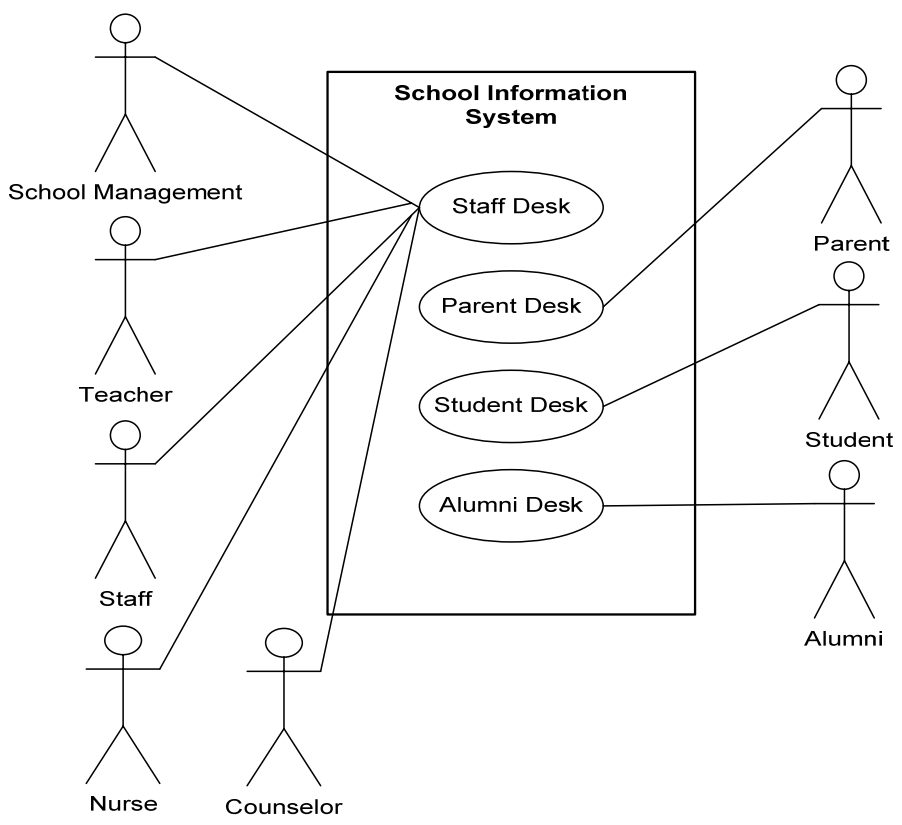

Gambar 2 High level use case diagram 
Pada low level use case diagram menggambarkan system use case yang mendefinisikan detail sub sistem dari setiap aktifitas proses bisnis pada sekolah yang berinteraksi dengan para pengguna sistem (school stakeholders).

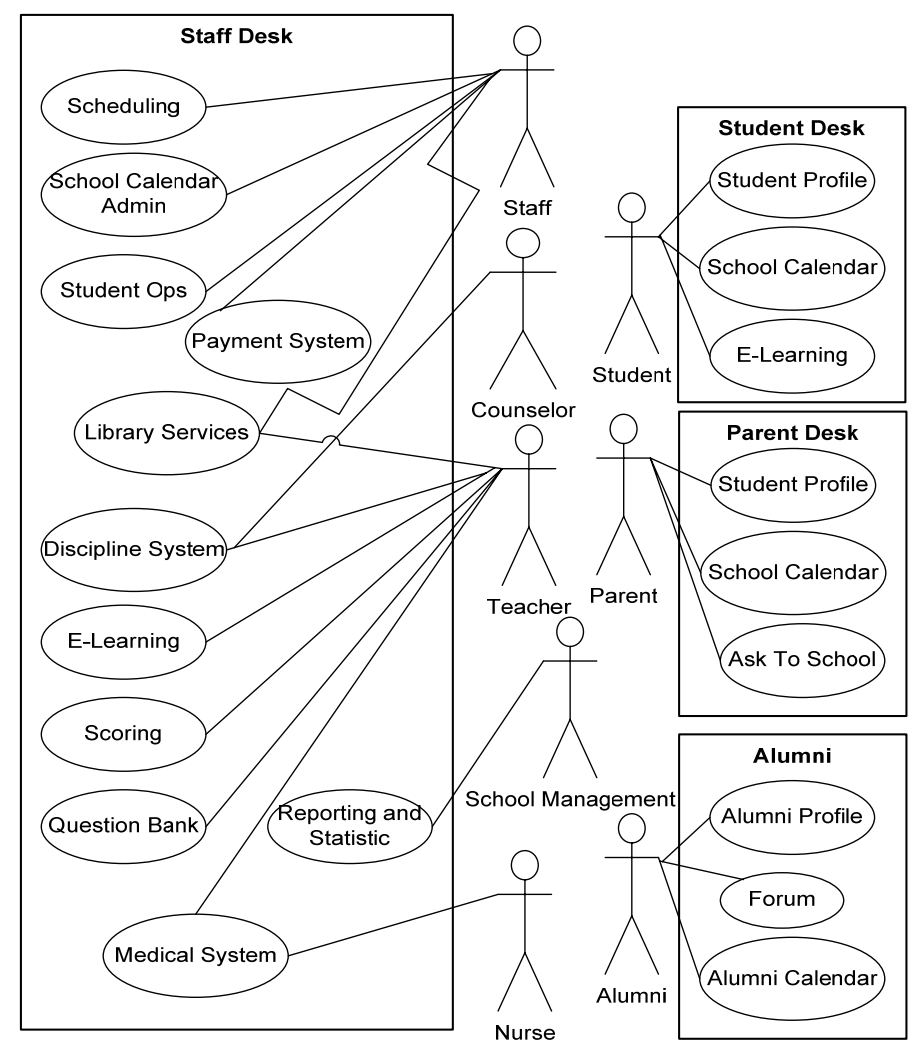

Gambar 3 Low level use case diagram

\section{Logical View}

Logical view menampilkan komponen-komponen (Objek-objek) dari sistem, serta menggambarkan interaksi/hubungannya. Saat ini, diagram yang umum digunakan untuk menciptakan model untuk logical view dengan UML Class Diagram, yang digambarkan dalam tujuh cluster, yaitu master, academic services, library, financial, clinic, event, dan content.

\section{Process View}

Process view menampilkan proses-proses dan aliran kerja dari sistem dan menggambarkan komunikasi antar proses bisnis yang berlangsung pada sekolah, dimulai dari proses registrasi siswa sampai dengan siswa tersebut menjadi alumni. Untuk menggambarkan process view digunakan UML activity diagram untuk menggambarkan proses utama dan alur kontrol sistem.

\section{Implementation View (Development)}

Pada implementation view digunakan component diagram untuk menampilkan komponen sistem yang digunakan pada saat pengoperasian (layer operasi). Struktur arsitektur komponen yang dipilih adalah client-server dengan pola Local Presentation. Di client adalah users dari sistem, hanya terdapat user interface yang akan melakukan request dan System Interface yang akan menyediakan 
akses terhadap function di server yang akan memproses dan memberikan respons yang diminta. Hal ini bertujuan untuk menjaga konsistensi data transaksi karena sistem dapat diakses melalui web oleh beberapa client yang berada pada lokasi yang berbeda. Data hanya terdapat di pusat karena antara tiap bagian perlu adanya integrasi, oleh karena itu model hanya akan terdapat di server untuk menjaga konsistensi data, dapat dilihat pada Gambar 6.

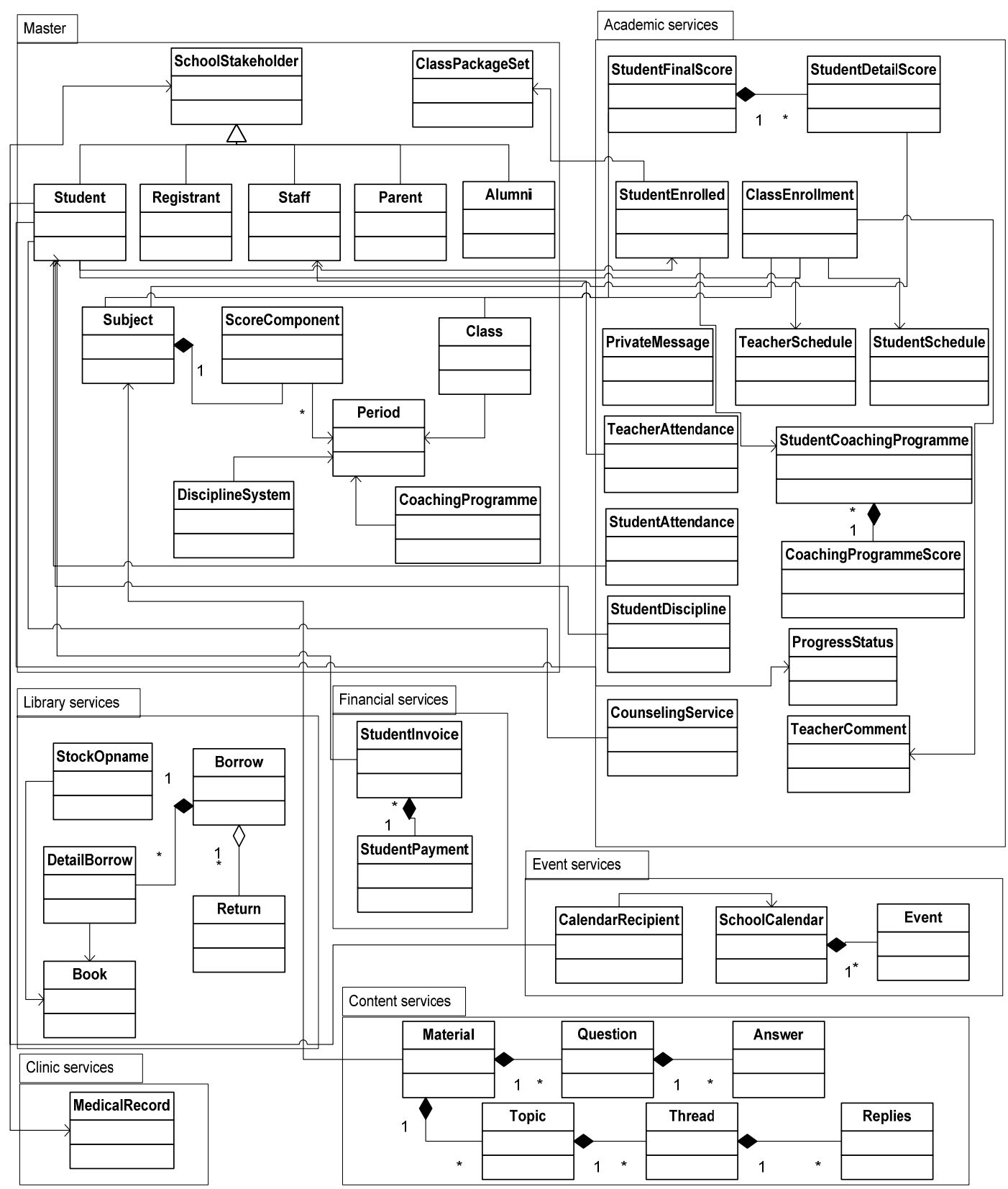

Gambar 4 Class diagram 


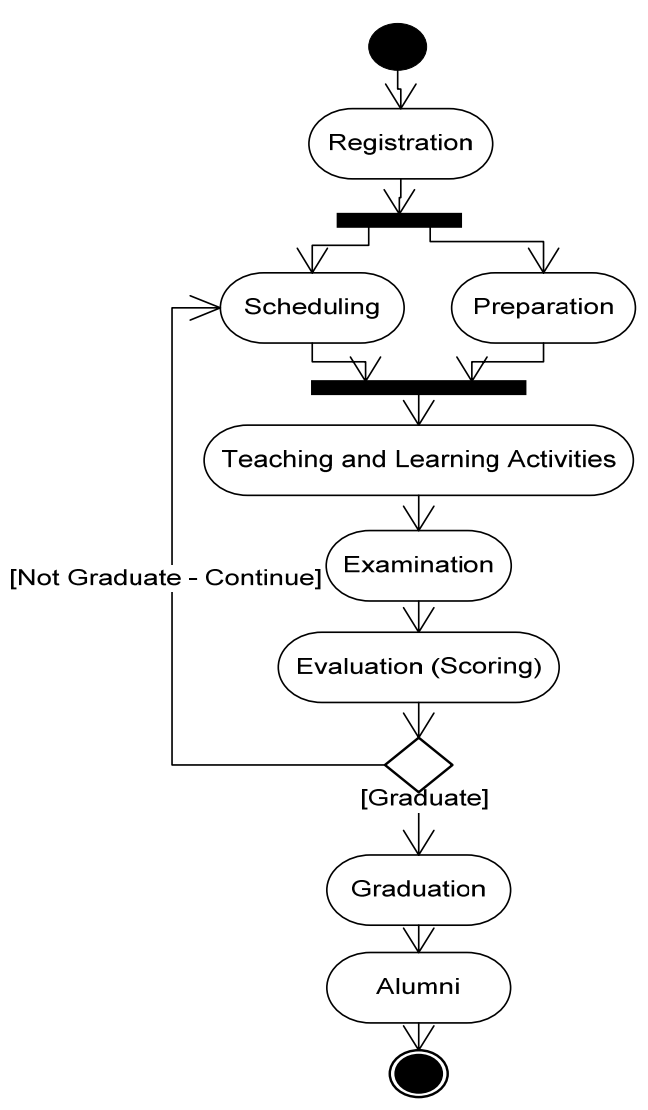

Gambar 5 Activity diagram

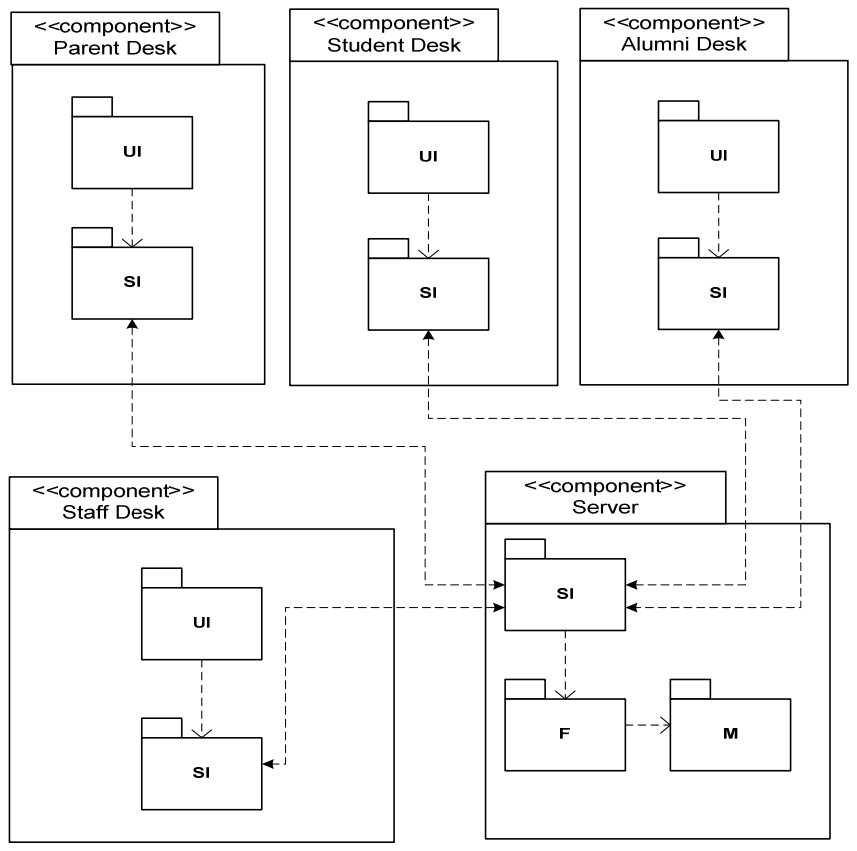

Gambar 6 Component diagram model sistem informasi manajemen untuk sekolah (sistem berbasiskan web) 


\section{Deployment View (Physical)}

Pada physical view digambarkan dengan menggunakan notasi UML deployment diagram untuk menggambarkan elemen struktural sistem secara umum yang digunakan untuk merepresentasikan physical deployment nodes (lingkungan sistem). Deployment diagram pada model sistem informasi manajemen digambarkan untuk model sistem berbasiskan web yang menampilkan lingkungan eksekusi sistem (hardware/software platforms), dapat dilihat pada Gambar 7.

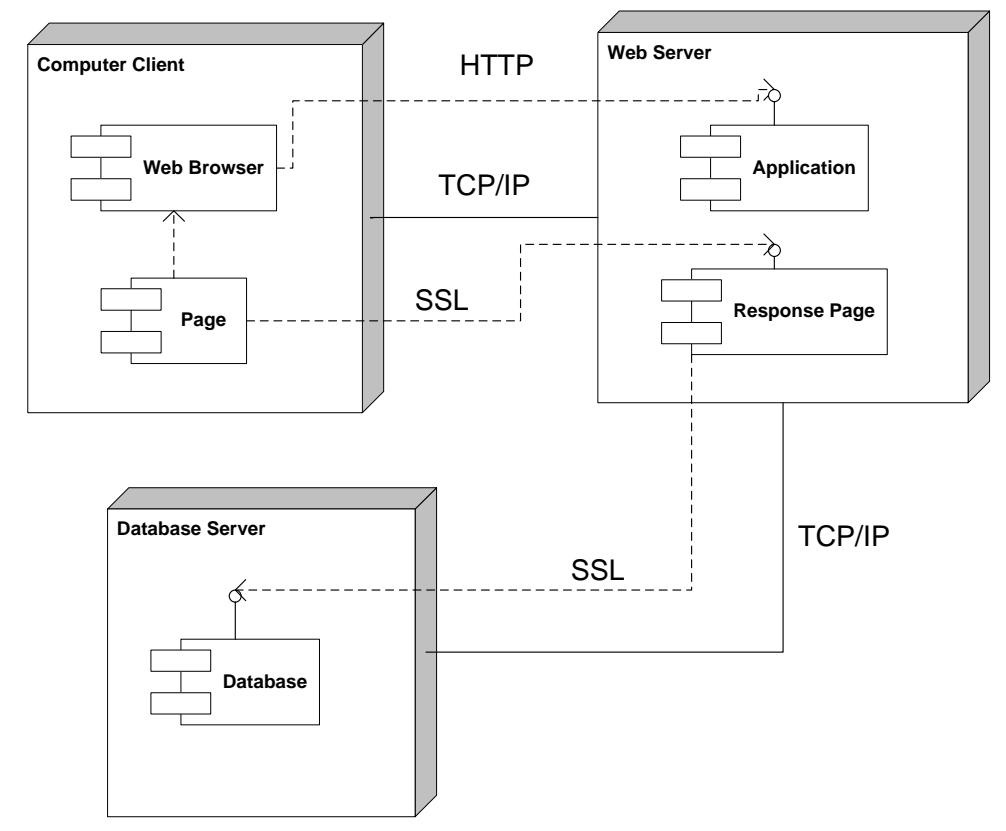

Gambar 7 Deployment diagram (berbasiskan web)

\section{PENUTUP}

Model sistem informasi manajemen untuk sekolah yang digambarkan pada penelitian ini dengan notasi UML (pendekatan 4+1 views) sebagai teknik pemodelan object oriented akan dapat membantu para developer aplikasi sistem informasi manajemen untuk mengerti sistem informasi manajemen sekolah secara jelas dan komprehensif. Model sistem informasi manajemen merupakan hasil analisis dan perancangan yang dapat digunakan untuk pengembangan perangkat lunak sistem informasi manajemen sekolah secara terintegrasi. Model ini dapat membantu menyederhanakan fungsionalitas yang ada pada sistem informasi manajemen, sehingga proses identifikasi kebutuhan sistem informasi manajemen menjadi lebih mudah dilakukan. Model sistem informasi manajemen untuk sekolah dapat digunakan sebagai pedoman perancangan sistem informasi manajemen pada sekolah.

\section{DAFTAR PUSTAKA}

Arlow, J., Emmerich,W., \& Quinn, J. (1999). Literate modeling-capturing business knowledge with the UML. The Unified Modeling Language: first international workshop selected paper/UML '98: Beyond the Notation, 189-199. London: Springer-Verlag. 
Carl, M. dan Lessing, L. (2005). A conceptual model for enterprise resource planning (ERP). Information Management \& Computer Security, 13 (2), 144 - 155.

Hitz, M., Kappel, G. (1999). Developing with UML some pitfalls and workarounds. The Unified Modeling Language: first international workshop selected paper/UML '98: Beyond the Notation, 9-20. London: Springer-Verlag.

Hruby, Pavel. (1998). Structuring Specification of Business Systems with UML (with an Emphasis on Workflow Management Systems. Diakses dari Pavel Hruby website: http://phruby.com/publications/OOPSLA98_BusinessObjectsIV.pdf.

Jacobson, I., Booch, G., \& Rumbaugh, J. (1999). The Unified Modeling Language User Guide. Boston: Addison Wesley.

Kruchten, P. (2012). Architectural Buleprints: The '4+1'View Model of Software Architecture. Diakses 10 Maret 2013 dari http://www.rational.com/uml/resources/whitepapers.

Park, J., Lee, N. (2006). A conceptual model of ERP for small and medium-size companies based on UML. International Journal of Computer Science and Network Security, 6(5A).

Ranjan, J. dan Khalil, S. (2007). Application of knowledge management in management education: a conceptual framework. Journal of Theoretical and Applied Information Technology, 3 (3), 2007.

Webber, C.F. (2003). New technologies and educative leadership. Journal of Educational Administration. 41 (2), 119 - 123.

Weber, R. (2000). Information System Controls and Audit. New Jersey: Prentice-Hall.

Worley, J. H., Chatha, K. A., Weston, R., Aguirre, O., dan Grabot, B. (2005). Implementation and optimization of ERP systems: a better integration of processes, roles, knowledge and user competencies. Journal of Computers in Industry, 56 (6), 620 - 638. 